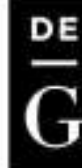

DOI 10.2478/pesd-2018-0003

PESD, VOL. 12, no. 1, 2018

\title{
ASSESSMENT OF REGIONAL VARIATION OF FLOOD RUNOFF IN THE REPUBLIC OF MOLDOVA
}

\begin{abstract}
Jeleapov Ana ${ }^{1}$
Key words: flood runoff, land cover, SCS-CN model, the Republic of Moldova

Abstract: Present study is dedicated to assessment and analysis of flood runoff and its spatial distribution in the limits of the Republic of Moldova. SCS-CN model and GIS were used as main methods and techniques for runoff assessment. Main components which were considered for flood runoff estimation are soils (soil texture and moisture condition), land cover and rainfall (for $1 \%$ probability). The results showed the region that is the most affected by flood runoff is northern part of the republic with flood runoff $>100 \mathrm{~mm}$, the lowest flood runoff values being estimated for the southern part of the country with $<50 \mathrm{~mm}$. Soil moisture conditions have a important impact on flood runoff amount, increasing its averages with 30 to $60 \%$ in case of wet condition and decreasing it with $35-65 \%$ in case of dry soil. It was also observed that flood runoff distribution is highly influenced by land cover, the average values being twice as high in urban area than under natural vegetation.
\end{abstract}

\section{Introduction}

River floods are the main hydrological disasters that occur on the territory of the Republic of Moldova. Extreme climatic conditions (heavy rains and/or snow melt) are the main factors which determine flood generation (Elaborarea modelului undei, 2009; Probleme de studiu a inundațiilor, 2002; Jeleapov, 2014; Jeleapov 2016; Melniciuc, 2012). Total losses caused by floods for last 70 years (19472015) constitute \$US 583 mil. from which a damage of \$US 20 mil. was made by spring floods, losses of \$US 232 mil. were determined by summer floods on big rivers and losses of \$US 331 mil. - over 55\% of total - were caused by fast slope runoff generated by heavy rains on small rivers (flash floods) (Productivitatea rurală în Moldova, 2007; Raport national, 2007; Raport national, 2011; Corobov et

\footnotetext{
${ }^{1}$ Institute of Ecology and Geography of the Academy of Sciences of the Republic of Moldova, email anajeleapov@gmail.com
} 
al., 2014; Palamarciuk \& Palamarciuk, 2000). Recent extremely intense floods, which occurred in 2008 and 2010 on big rivers of Moldova: the Dniester and Prut, produced a damage of \$US 196 mil. (Melniciuc, 2012). Thus, the most significant losses are caused by the summer floods on big rivers, when large water volumes flow from the upper parts of the basins situated in Ukraine, but especially by small rivers floods (flash floods) that are generated by heavy rains. The most affected regions are the floodplains with huge water accumulation capacity: downstream part of big rivers Prut and Dniester. Less studied are flash floods processes. Present study is dedicated to assessment of flood runoff for elementary river basins as well as for territorial-administrative units of the Republic of Moldova and its spatial variation according to its generation factors.

Increasing degree of human impact on the environment remains to be one of the main factors determining the modification of environmental features as well as natural processes such as flood runoff generation.

Estimation of flood runoff and its changes under anthropogenic activities depends on quality and quantity of hydrologic data which often is absent or insufficient. In such cases, the best option consists of application of indirect methods. So far, flood runoff calculation methodology has significantly progressed and a lot of different methods, models and techniques were developed and implemented all over the world. In the Republic of Moldova normative acts (Normativ în construcții, 2013), two main methodological principles, that are applied to evaluate the flood runoff, are the following: statistical analysis of time series using the database from hydrologic monitoring network stations and modeling of maximal discharge of different probabilities using rational and genetic equations (Normativ în construcții, 2013; Elaborarea modelului undei, 2009; Probleme de studiu a inundațiilor, 2002; Melniciuc, 2012).

At international level, a big popularity for flood runoff calculation was gained by Soil Conservation Service Curve Number model (SCS-CN) (SCS, 1956, SCS, 1972). This model was successfully applied for estimation of flood runoff changes under land cover impact on example of the Byc River basin situated in the central part of the Republic of Moldova (Jeleapov, 2016). In present study, the model was used for assessment of regional variation of the flood runoff for entire country. Utilization of SCS-CN model is suitable for evaluation of human impact on runoff expressed by land cover changes, climate variations, modification of soil texture and moisture conditions under agricultural activities. A great advantage for application of this model is utilization of GIS techniques for calculations and spatial representation of input data and results.

Estimation of changes which occur in hydrological and social system is the basic objective of the scientific decade 2013-2022 of International Association of 
Hydrological Sciences (IAHS) called "Panta Rhei - Everything Flows: Change in Hydrology and Society" (Montanari et. al., 2013).

In this context, present study, which reflects the theme of flood runoff and its spatial distribution under the influence of natural and anthropogenic factors, is perfectly integrated in research direction chosen by the hydrological scientific community for the next decade.

\section{Study area}

Assessment of flood runoff was performed for 789 small river basins as well as for 984 elementary territorial-administrative units of the Republic of Moldova 928 villages with commune status, 5 municipalities and 51 towns.

The Republic of Moldova is situated in south-eastern part of Europe, close to its geographic center. The topography of the country represents a hilly plain with average elevation equal to $148 \mathrm{~m}$. which varies from $429 \mathrm{~m}$. and $-4 \mathrm{~m}$. (fig. 1) (Resursele naturale, 2006).

The climate is moderately continental, average annual temperatures increase from $8.4-9.5^{\circ} \mathrm{C}$ in the north to $10-11^{\circ} \mathrm{C}$ in the south. Average sum of precipitation constitute 550-700 in the north-west decreasing to $434-500 \mathrm{~mm}$ to the south-east (Atlas, 2013). Maximal amount of daily precipitation increases up to $150-230 \mathrm{~mm}$ (Hazardurile naturale, 2008; Probleme de studiu a inundațiilor, 2002, Jeleapov 2014, Melniciuc, 2012). As usual, extreme rainfall are characteristic for summer period.

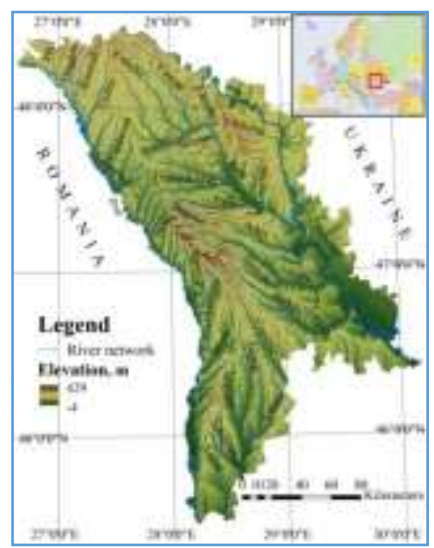

Figure 1. Study area - the Republic of Moldova

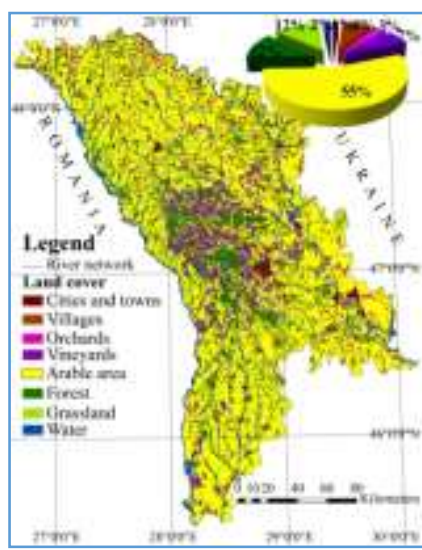

Figure 2. Land use/cover (Harta FAO, 2005)

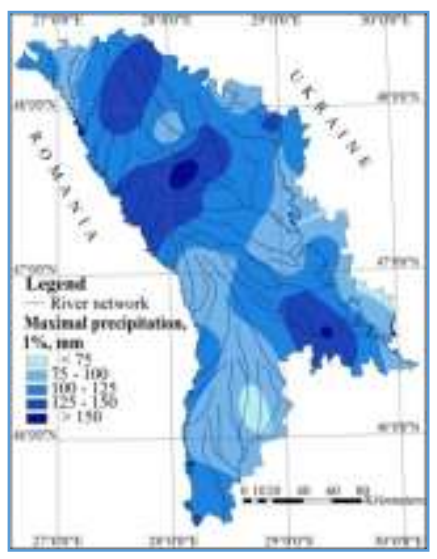

Figure 3. Rainfall of $1 \%$ probability, mm

Land use/cover is mostly characterized by arable area with the rate of $55 \%$, $\sim 24 \%$ is covered by forest and grassland (each $12 \%$ ), urban and rural area occupy 
$10 \%$ of the territory. Natural cover (forest and grassland) as well as orchards are predominant for central part of the republic, the northern and southern being arable area (fig. 2).

Moldova soil cover of is fertile and consists of more than 700 varieties. Chernozems occupy around $70 \%$ of country area (Resursele naturale, 2006). In accordance with soils hydrological classes description (Stematiu \& Drobot, 2007), the biggest portion of the country is occupied by the $\mathrm{C}$ hydrological class soils $(>60 \%)$. The A class soils with the share of $\sim 2 \%$ as well as B class soils $\sim 25 \%$ is distributed in the central and southern part of Moldova, D class soil $(\sim 10 \%)$ is situated mostly in the northern part of the country (Harta texturii solului, 2016). So the most part of the country is occupied by soils of low infiltration rate and high runoff potential.

The country river network is formed by over 3000 rivers from which only 256 rivers have a length of $>10 \mathrm{~km}$. Main rivers are Dniester and Prut with average flow of 300 and $80 \mathrm{~m}^{3} / \mathrm{s}$ respectively, more smaller are: Raut, Cogylnic, Byc, Botna and others (Boboc \& Jeleapov, 2014; Resursele naturale, 2006).

\section{Methodology and data base}

Flood runoff generation depends on many factors that as usual are difficult to appreciate due to their complexity. SCS-CN model integrates several of the most important of them: heavy rains, land cover and soils. The SCS-CN model was developed by the Natural Resources Conservation Service (previously called Soil Conservation Service, USDA) to predict direct flood runoff for given rainfall events (SCS, 1956; SCS, 1972). The concept of the method is based on the conventional representation of the maximum retention potential during rainfall (Bilasco, 2008), which is influenced by land cover types, soil hydrological group and extreme precipitation which is based on water balance equation that was subsequently modified for different purposes:

$$
\begin{array}{ll}
\quad Q=P-I s-I-E-d & \text { (1) } \\
\text { where: } & I \text { - interception, mm } \\
Q \text { - runoff, } \mathrm{mm} & E \text { - evapotranspiration, } \mathrm{mm} \\
P \text { - rainfall, } \mathrm{mm} & n \text { - other types of retention }
\end{array}
$$

Main formula used in present study for implementation of SCS-CN model is the following (Costache et al., 2014; Dawod et al., 2013; Ponce \& Hawkins, 1996):

where:

$$
Q=\frac{(P-0.2 * S)^{2}}{P+0.8 * S}
$$

$Q$ - direct (surface) runoff, mm 
$\mathrm{S}$ - potential for water retention, $\mathrm{mm}$, which is estimated by:

where:

$$
S=\frac{25400}{C N}-254
$$

$C N$ - the curve number which results from the intersection between land cover and soil hydrological group, estimated according to Stematiu \& Drobot, (2007). $C N$ is estimated depending on antecedent soil moisture conditions (ASM): low moisture or dry soils (ASM I), average soil moisture condition (ASM II) and high moisture or wet soils (ASM III).

All the factors that are integrated in the SCS-CN model: soil, rainfall, land cover as well as calculated $\mathrm{CN}, \mathrm{S}$ and Q itself can be spatially represented using GIS techniques. Schematic representation of steps for estimation of flood runoff using SCS-CN model and GIS is represented in figure 4.

Assessment of spatial distribution of main components for SCS-CN model application was performed using and combining digital land cover (Harta FAO, 2005) and soil maps (Harta texturii solului, 2016), GIS interpolation techniques for rainfall mapping (An overview, 2016) and for calculation of flood runoff basing on equations (2) and (3). Spatial structure of land cover was estimated using FAO land cover map (Harta FAO, 2005) which was classified into 9 classes:

1. Towns and cities (Urban area)

2. Villages (Rural area)

3. Grassland
4. Orchards
5. Forest
6. Vineyards

7. Arable area

8. Rivers

9. Lakes and reservoirs

One of the most important components for flood runoff estimation is soil. This element was analyzed from perspective of runoff potential and infiltration rates basing on soil texture. Spatial distribution of soil texture was extracted from soil maps from Moldova's national geospatial data fund from www.geoportal.md. Digital elevation model and slope was derived from 90m SRTM (2014).

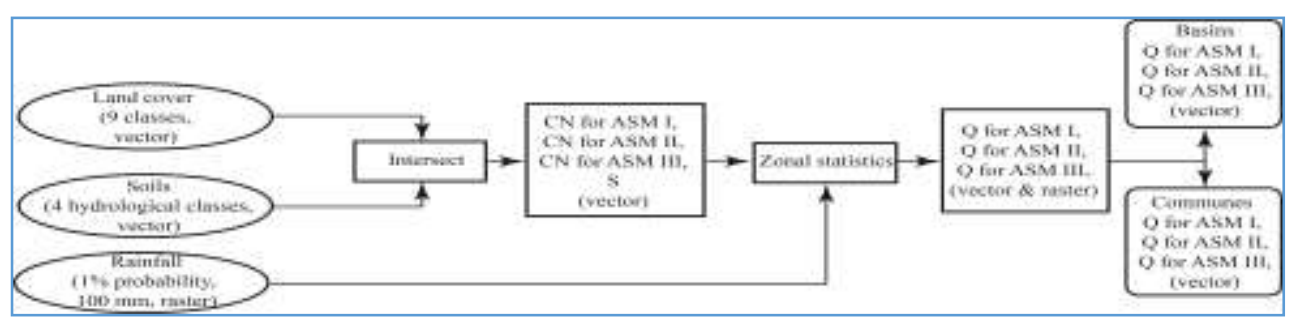

Figure 4. Schematic calculation of flood runoff using G.I.S. and SCS-CN model

Spatial distribution of rainfall - main generators of floods - is a challenging task due to its high spatial variation. For present study for modeling of 
precipitation map, there were used values of $1 \%$ probability calculated for 45 meteorological posts which were identified in annexes of national normative acts (Normativ în constructii, 2013). These values were interpolated and converted to raster format using GIS and applied to evaluate the flood runoff with SCS-CN model (fig. 3).

\section{Results and discussions}

Estimation of flood runoff spatial distribution was performed for 2 scenarios: for the case when the maximum precipitations are equal to $1 \%$ probability values, and for the case when these are equal to $100 \mathrm{~mm}$, in order to eliminate this factor effect and to estimate the net land cover impact on runoff. For both scenarios, soil moisture was considered as low, medium and high and land cover remained constant. As a result, 6 cartographic models (rasters) were obtained (fig. 7-12), based on which, it was estimated that the average values of the flood runoff for scenario I is $63,8 \mathrm{~mm}$ in case of soil average moisture condition, $31,4 \mathrm{~mm}$ - in case of dry soils and $90,7 \mathrm{~mm}$ for wet soil, for scenario II these values are approx. 10 mm smaller (table 1).

Table 1. Differences in flood runoff depending on soil moisture and maximum precipitation

\begin{tabular}{|c|c|c|c|c|c|}
\hline \multicolumn{5}{|c|}{ Flood runoff, mm for } \\
\hline \multicolumn{3}{|c|}{ Scenario I } & \multicolumn{3}{c|}{ Scenario II } \\
\hline \multicolumn{2}{|c|}{ Rainfall of 1\% probability, mm } & \multicolumn{3}{c|}{ Rainfall of 100 mm } \\
\hline $\begin{array}{c}\text { Soil average } \\
\text { moisture } \\
\text { condition }\end{array}$ & $\begin{array}{c}\text { Soil low } \\
\text { moisture } \\
\text { condition }\end{array}$ & $\begin{array}{c}\text { Soil high } \\
\text { moisture } \\
\text { condition }\end{array}$ & $\begin{array}{c}\text { Soil average } \\
\text { moisture } \\
\text { condition }\end{array}$ & $\begin{array}{c}\text { Soil low } \\
\text { moisture } \\
\text { condition }\end{array}$ & $\begin{array}{c}\text { Soil high } \\
\text { moisture } \\
\text { condition }\end{array}$ \\
\hline 63,8 & 31,4 & 90,7 & 53,5 & 24,0 & 79,3 \\
\hline
\end{tabular}

The results obtained with the SCS-CN model were compared with the flood runoff values calculated according to recommendations from national normative document (SNIP) (Normativ în construcții, 2013) which suggests to estimate the flood runoff by multiplying maximal precipitations with runoff coefficient. Correlation of flood runoff values, estimated with two methods, extracted for 26 river basins resulted in correlation coefficient equal to 0.79 - quite satisfactory to confirm the possibility of SCS-CN model application on the territory of the Republic of Moldova (Figure 5).

Flood runoff depends largely on rainfall amount, which is quite nonuniform, from point of view of both spatial distribution as well as these values amplitudes, the maximum reaching $180 \mathrm{~mm}$. For assessment of runoff generated by maximum precipitations, regionalization was made by calculation of flood runoff average values for river basins as well as for territorial-administrative units where precipitations are $\leq 100 \mathrm{~mm}, 100-150 \mathrm{~mm}$, and $\geq 150 \mathrm{~mm}$, respectively. Obviously, 
the most flood-affected regions are those where maximum precipitation values exceed $150 \mathrm{~mm}$. Thus, in these regions flood runoff values will exceed $100 \mathrm{~mm}$, being estimated for the northern part of the republic, especially, for the districts Donduseni, Singerei, Falesti, but also for certain regions from East - Causeni and Stefan Voda - and West - Ungheni, Nisporeni. The average flood runoff at commune/basin level will increase above $130 \mathrm{~mm}$ in case of wet soil and will decrease below $60 \mathrm{~mm}$ in case of dry soil conditions.

The lowest flood runoff values are estimated for the southern and eastern part of the country in conditions when $1 \%$ rainfall is bellow $100 \mathrm{~mm}$. Thus, in the limits of districts Dubasari, Criuleni, Straseni, Hyncesti, Leova, Basarabeasca, UTA Gagauzia there are situated basins and communes with the lowest flood runoff which is less than $50 \mathrm{~mm}$, decreasing under $20 \mathrm{~mm}$ for dry soil and increasing up to $70 \mathrm{~mm}$ for wet soils.

Flood runoff is significantly influenced by soil features. Its changes appreciation was made by estimating the flood runoff average values for basins and administrative-territorial units where the predominance of a hydrological group of soils with a rate over $50 \%$ is observed. Differences in flood runoff generated on land covered by soils of different texture, show that soils of D hydrological group cause an increase of runoff with about $13 \%$ and $30 \%$, respectively, compared to those of $\mathrm{C}$ and $\mathrm{B}$ groups. Average flood runoff for communes and basins where soils of D hydrological group predominate $(>50 \%$ of total area) constitute 75 $80 \mathrm{~mm}$ for average soil moisture, $41-46 \mathrm{~mm}$ for dry soils and $99-106 \mathrm{~mm}$ for wet soils. In case when C class soils prevail, the average flood runoff is $66-67 \mathrm{~mm}$ for ASM II, $33 \mathrm{~mm}$ in case of ASM I and $94 \mathrm{~mm}$ in case of ASM III (fig. 13). Thus, soil moisture conditions as well as soil structure have a important impact on flood runoff amount. The values can increase from 30 to $60 \%$ in case of high moisture conditions caused by antecedent precipitation or by irrigation process, and, respectively, can decrease by $35-65 \%$ in case of dry soil. The continuous process of soil compaction by agricultural technique influence, will lead to an increase of the flood runoff by about $26 \%$ under ASM II conditions, $38 \%$ in case of ASM I and $17 \%$ for ASM III. Approximately the same rules are maintained in the case of flood runoff modeling using as rainfall event $100 \mathrm{~mm}$ precipitations (fig. 14).

A special attention was paid to flood runoff spatial variation under different land cover types (fig. 15). Assessment of flood runoff changes was performed by comparison of averages for basins and communes where, with the rate $>50 \%$, natural cover (forests), as well as lands, moderately and heavily modified by anthropogenic activity: perennial plantations, arable area and settlements. Modeling results showed a logical increase of flood runoff from natural to urbanized cover. The lowest flood runoff is estimated under forest cover and represents $44 \mathrm{~mm}$ for average soil moisture, $17 \mathrm{~mm}$ for ASM I and $73 \mathrm{~mm}$ for 
ASM III. A slightly higher runoff is specific for basins where perennial plantations prevail, $50 \mathrm{~mm}$ - for ASM II, 20mm - for ASM I, $78 \mathrm{~mm}$ for ASM III. Arable area has a greater impact of flood runoff generation. Its amounts increases to $66 \mathrm{~mm}$ in case of average soil moisture, $33 \mathrm{~mm}$ for dry soils and $92 \mathrm{~mm}$ for wet soils. The highest flood runoff was modeled for urbanized area, its values being of $70 \mathrm{~mm}$ for ASM II, $40 \mathrm{~mm}$ for soil with for ASM I and $90 \mathrm{~mm}$ for those with for ASM III. Flood runoff increases under urbanization processes by $50 \%$ compared to regions where natural vegetation is predominant. Approximately, the same rules but with lower flood runoff average values were estimated for second scenario (fig. 16).

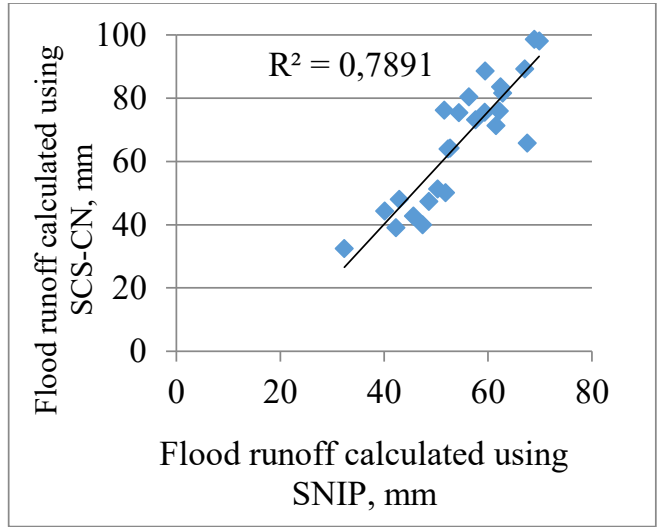

Figure 5. Correlation between flood runoff estimated by SCS-CN and SNIP method
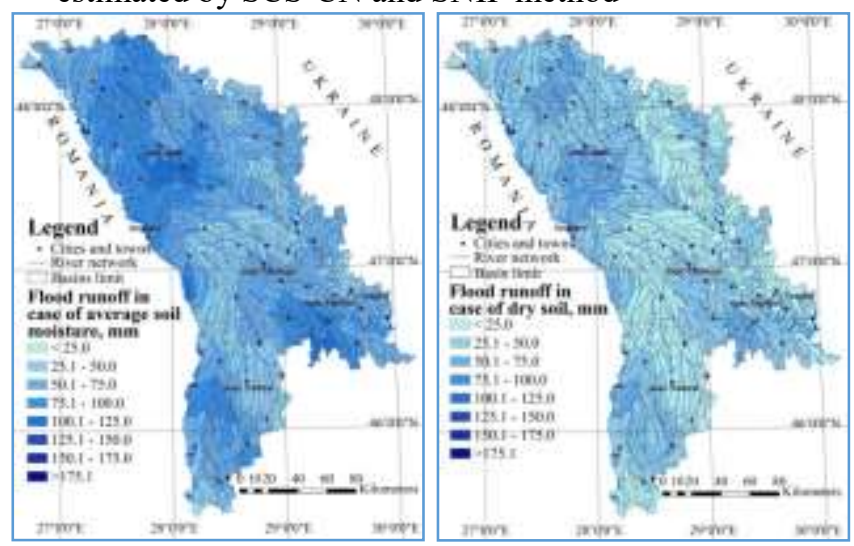

Figure 7. Flood runoff in case Figure 8. Flood runoff in case of ASM II, $1 \%$ precipitation, of dry soil, $1 \%$ precipitation, small basins

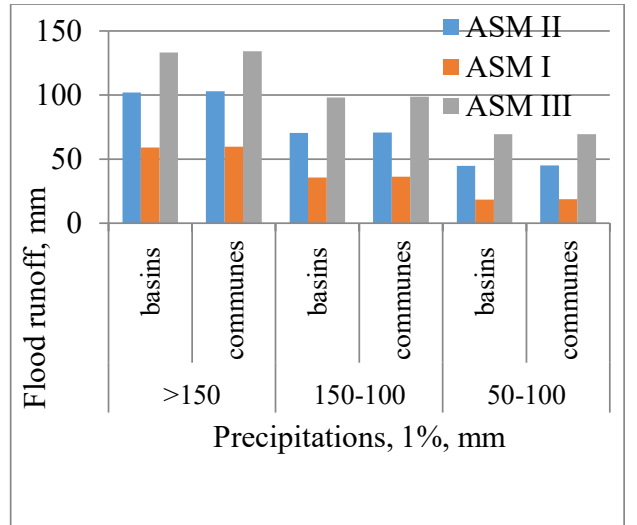

Figure 6. Flood runoff changes under 1\% rainfall impact

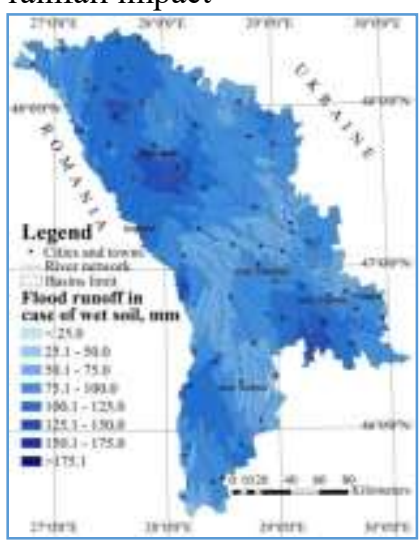

Figure 9. Flood runoff in case of wet soil, $1 \%$ precipitation, small basins 


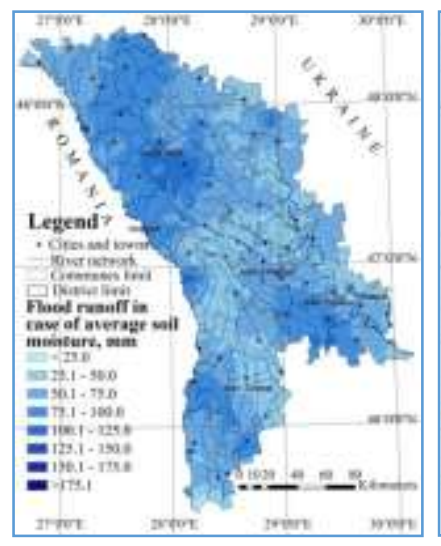

Figure 10. Flood runoff in case of ASM II, $1 \%$

precipitation, communes

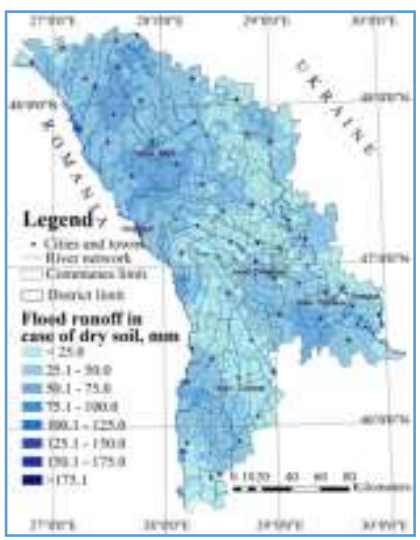

Figure 11. Flood runoff in case of dry soil, $1 \%$ precipitation, communes

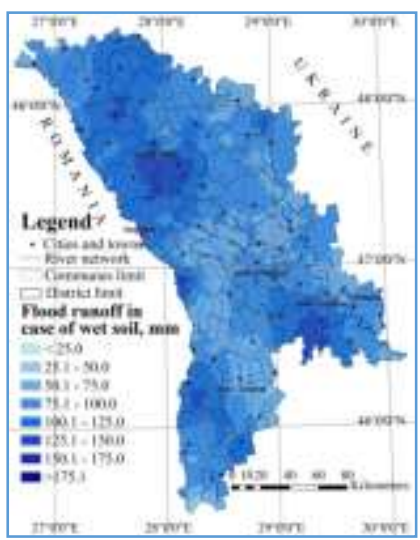

Figure 12. Flood runoff in case of wet soil, $1 \%$ precipitation, communes

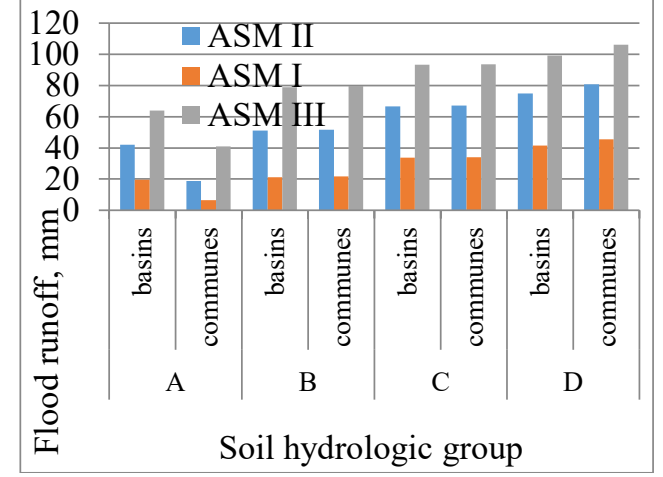

Figura 13. Flood runoff changes under soil cover impact, $1 \%$ precipitation

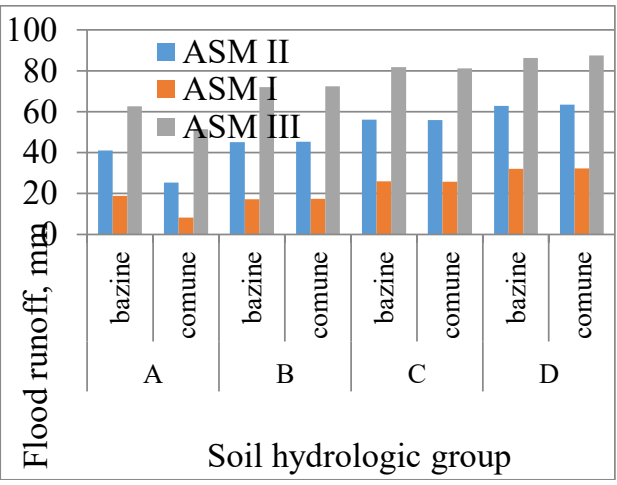

Figura 14. Flood runoff changes under soil cover impact, $100 \mathrm{~mm}$ precipitation

Current recommendations for sustainable development in the field of water resources, water bodies protection are directed towards naturalization of rivers by reducing human impact expressed by both point and diffuse pollution as well as hydromorphological alterations (2000/60/EC Directive, 2000). Rivers naturalization activities are resumed to restoration of natural conditions, maintaining a sustainable management and determining an anthropogenic impact that would not exceed the maximum permissible limits. Current land use trends shows that over $50 \%$ of the territory of the Republic of Moldova is occupied by arable area. Changing land use from arable to natural would be a first step in restoration of rivers natural flow. In order to estimate flood runoff changes that may occur in the case of land use change, there have been made a test to estimate 
the relationship between land cover and flood runoff. For this purpose, it was attempted to determine the multiple regression equation using STATGRAPHICS program (2017). The following data were used: flood runoff, the rate of land use types and $1 \%$ probability rainfall, estimated for 789 small basins. Finally, the regression equation (4) was obtained. In order to eliminate the impact of maximum precipitations spatial distribution, there was calculated the regression equation between the flood runoff and land use types rates which resulted in equation (5).

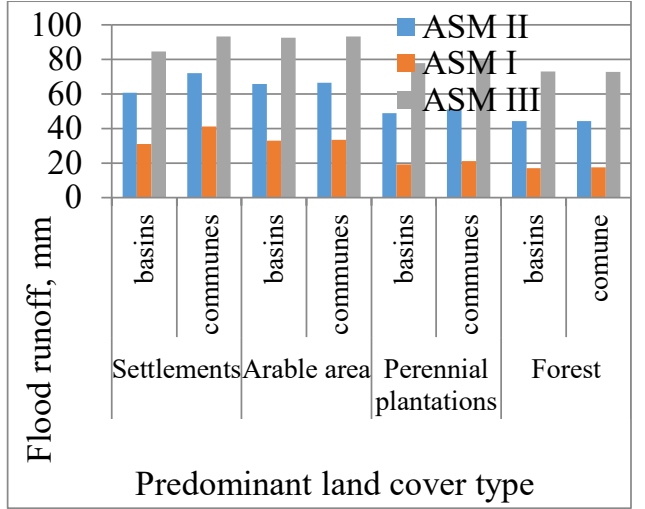

Figura 15. Flood runoff changes under land cover impact, $1 \%$ rainfall

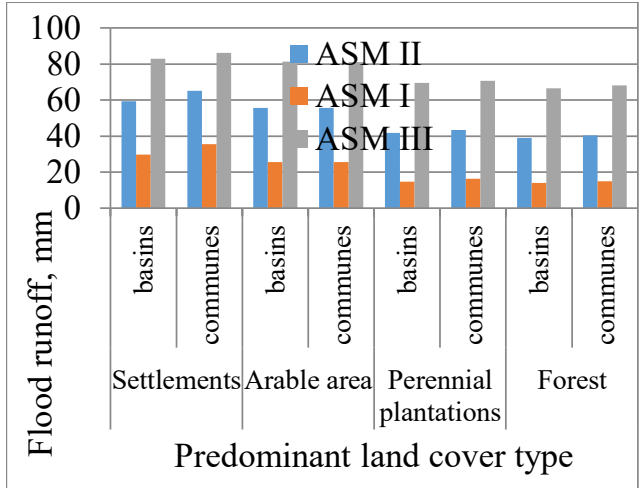

Figura 16. Flood runoff changes under land cover impact, $100 \mathrm{~mm}$ rainfall

$$
\begin{aligned}
& Y_{\text {reg1 }}=-118.841+0.622161 * P r_{\text {Forest }}+0.946481 * P r_{\text {Grassland }} \\
& +0.973797 * P r_{\text {Ruralsetlements }}+0.587012 * P r_{\text {Vineyards }} \\
& +0.882476 * 1 \% \text { Precipitations }+0.891529 * P r_{\text {Arable }} \\
& +0.756157 * \text { Pr } r_{\text {orchards }}+1.04003 * P r_{\text {Urbansettlements }} \\
& Y_{\text {reg } 2}=-25.2683+0.920384 * P r_{\text {Ruralsetlements }}+0.975952 \\
& * P r_{\text {Urbansettlements }}+0.58122 * P r_{\text {Forest }}+0.899814 \\
& * P r_{\text {Grassland }}+0.542697 * P r_{\text {Vineyards }}+0.83569 * P r_{\text {Arable }} \\
& +0.692535 * \text { Pr } r_{\text {orchards }}
\end{aligned}
$$

For correlation of flood runoff values estimated using SCS-CN and multiple regression equations, the graphs from figures 17 and 18 have been constructed, showing a relatively high relationship between modeled characteristics. Thus, the coefficient of determination for assessment of equation (4) is $92 \%$, and in the case of precipitation impact removal, the correlation between modeled features is $52 \%$. Maximum rainfall is a determinant factor in the process of flood runoff generation, but water retention by the vegetation plays also a significant role. In spite of the fact that correlation coefficient estimated between values calculated using formula (5) and SCS-CN model is at the limit of permissible values, points position within 
the coordinate system forms an integral cloud and shows the contribution of surface retention factor in flood generation.

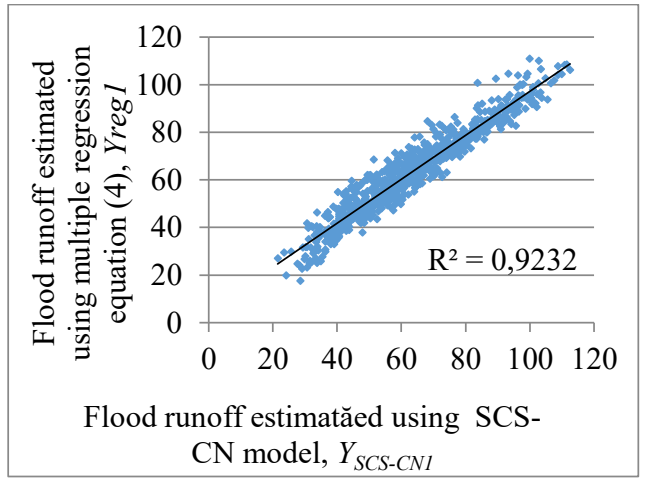

Figure 17. Correlation between flood runoff modeled with SCS-CN and multiple regression

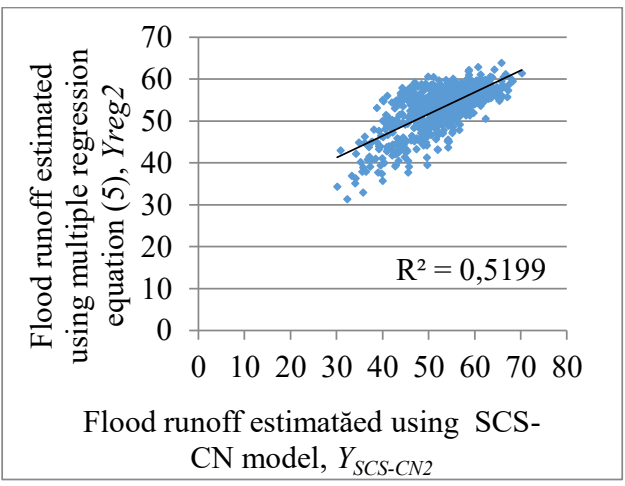

Figure 18. Correlation between flood runoff modeled with SCS-CN and multiple regression without $1 \%$ precipitation

\section{Conclusions}

Presented study highlights assessment and spatial variation of flood runoff in the limits of the Republic of Moldova. Overall, average flood runoff for the republic is equal to $63,8 \mathrm{~mm}$ in case of ASM II, 31,4mm for ASM I and $90,7 \mathrm{~mm}$ for ASM III for scenario that considers $1 \%$ precipitation. The highest values can be observed in the basins and communes where $1 \%$ rainfall exceeds $150 \mathrm{~mm}$, runoff being over $100 \mathrm{~mm}$. In condition when the biggest rate of the area is dominated by $\mathrm{D}$ class soils and settlements, flood runoff is equal to $60-80 \mathrm{~mm}$. The lowest values are characteristic for regions where natural cover, especially forest, is dominant, $1 \%$ rainfall is less than $100 \mathrm{~mm}$ and there where B soil class covers over $50 \%$. Here the flood runoff slowly exceeds $18-45 \mathrm{~mm}$.

Research results can serve as an argument for further estimation of flood characteristics in ungauged basins, planning and construction of hydrotechnical structures, civil engineering activities. Presented maps of flood runoff at bazinal and communes level can serve as support for local authorities and decision makers during process of land use practices optimization, development of plans for better land, water resources and flood management.

Improvements of research results can be carried out by field measurements for estimation of relationship between soil classes and land cover types and to calibrate $\mathrm{CN}$ for condition of the Republic of Moldova. Other important activity consists of more accurate estimation and spatial distribution of extreme rainfall that can 
change overall estimation flood runoff variation. In general, SCS-CN model represents big potential for flood runoff calculation and is recommended for further development and application on the rivers of the Republic of Moldova.

\section{References}

1. Bilasco S. (2008), Implementarea G.I.S. în modelarea viiturilor de versant, Casa Cărţii de Ştiinţă, Cluj-Napoca, 212 p.;

2. Boboc N., Jeleapov A. (2014), Resursele de apă din Regiunea de Dezvoltare Centru, Dezvoltarea durabilă a Regiunii de Dezvoltare Centru: factori de mediu și contribuții, Chișinău, p. 15-18;

3. Stematiu D., Drobot R. (2007), Metodologia pentru determinarea bazinelor hidrografice cu caracter torenţial în care se află aşezări umane expuse pericolului viiturilor rapide, UTCB, 29 p.;

4. Corobov R., Trombitkii I., Syrodoev G. Andreeva A., (2014), Vulnerability to climate change: the Moldavian part of the Dniester river basin: Monograph Chisinau, 336 p. (published in Russian);

5. Costache R., Fontanine I., Corodescu E. (2014), Assessment of surface runoff depth changes in Saratel River basin, Romania using GIS techniques, Cent. Eur. J. Geosci. 6 (3), p. 363-372;

6. Dawod G. M., Mirza M. N., Al-Ghamdi K. A., (2013), Assement of several flood estimation methodologies in Makkah metropolitan area, Saudi Arabia, Arabian Journal of Geoscience, 6(3), p. 985-993;

7. Jeleapov A. (2014), Flood wave modeling and assessment of flood hazard/risk areas in the Byc River Floodplain, Buletinul Institutului de Geologie şi Seismologie al AŞM, N.1, Chișinău, p. 57-69;

8. Jeleapov A. (2016), Assessment of flood runoff changes under land cover impact using SCS-CN model and GIS techniques. Case study: the Byc river basin, Moldova. GeographiaNapocensis, X, nr. 2, Cluj-Napoca, p. 101-108;

9. Melniciuc O., (2012), Pluvial floods and inundations on the rivers of Moldova Chisinau: Primex, 233 p. (published in Russian);

10. Montanari A., Young G., Savenije H.H.G., Hughes D., Wagener T., Ren L.L., Koutsoyiannis D., Cudennec C., Toth E., Grimaldi S., Blöschl G., Sivapalan M., Beven K., Gupta H., Hipsey M., Schaefli B., Arheimer B., Boegh E., Schymanski S.J., Di Baldassarre G., Yu B., Hubert P., Huang Y., Schumann A., Post D.A., Srinivasan V., Harman C., Thompson S., Rogger M., Viglione A., Mcmillan H., Characklis G., Pang Z. Belyaev V. (2013), "Panta Rhei-Everything Flows": Change in hydrology and society - The IAHS Scientific Decade 2013-2022 Hydrological Sciences Journal, 58 (6), p. 1256-1275;

11. Palamarciuk G., Palamarciuk A., (2000), Assessment of the water resources assurance of Moldova in perspective. Schimbarea climei cercetări, studii, soluţii, Culegere de lucrări, Chisinau, p. 73-80 (published in Russian). 
12. Ponce V. M., Hawkins R. H., (1996), Runoff curve number: has it reached maturity, Journal of Hydrologic Engineering, 1(1), p. 11-19;

13.**(2013), Atlas. Resursele climatice ale Republicii Moldova=Atlas. Climatic resources of the Republic of Moldova, colectiv de autori: Nedealcov M., Răileanu V., Chirică L. ș.a.; Chișinău, 76 p.;

14.***(2013), Determinarea caracteristicelor hidrologice pentru condițiile Republicii Moldova. Normativ in construcții CP D.01.05-2012, ediție oficială. Agenția construcții și dezvoltarea teritoriului Republici Moldova, Chișinău, 155 p.;

15.**(2009), Elaborarea modelului undei cinematice a viiturilor si evaluarea zonelor de risc in caz de inundații pe râurile din Republica Moldova. Dare de seama științifica, IEG ASM. Coordonator: Melniciuc O., Chișinău, 95 p;

16.***(2005), Harta FAO „Acoperirea/utilizarea teritoriului Republicii Moldova”, http://canteav.blogspot.md/ (accessed on 3.04.2013);

17. ***Harta texturii solului www.geoportal.md (accessed on 3.07.2016);

18. ***(2008), Hazardurile naturale. Colecţia Mediul geografic al Republicii Moldova, Compilat: Cazac V., Boian I., Volontir N. Chişinău, 207p.;

19.***(2002), Probleme de studiu a inundațiilor in Republica Moldova. Dare de seama științifică IEG ASM. Coordonator: Melniciuc O., CIAPI-Moldova, Chișinău, 115 p.;

20. ***(2007), Productivitatea rurală în Moldova - gestiunea vulnerabilităţii naturale. Banca mondială, 112 p.;

21.***(2006), Resursele naturale. Colecţia Mediul geografic al Republicii Moldova, compilat: Mihailescu C., Sochirca V., Constantinov T., ş.a, Chişinău, 184 p.;

22.***(2007), Starea mediului în Republica Moldova în anul 2006 Raport naţional. Chișinău, 103 p.;

23. ***(2011), Starea mediului in Republica Moldova in 2007-2010 (Raport național). Chișinău, 192 p.;

24. ***An overview of the Raster Interpolation toolset, http://pro.arcgis.com/en/proapp/tool-reference/3d-analyst/an-overview-of-the-interpolation-tools.htm (accessed on 12.12 .2016$)$

25. ***(2000), 2000/60/EC Directive of the European Parliament and of the Council of 23 October 2000 establishing a framework for Community action in the field of water policy., Official Journal of the European Communities, L 327/1-72,

26.***(2014), Shuttle Radar Topography Mission (SRTM), US Geological Survey https://earthexplorer.usgs.gov/ (accessed on 3.04.2017);

27.***(1956), Soil Conservation Service (SCS): Hydrology, National Engineering Handbook, Supplement A, Sect. 4, Chapt. 10, USDA, Washington, D.C., 70p;

28.**(1972), Soil Conservation Service (SCS): National Engineering Handbook, Supplement A, Sect. 4, Hydrology, Chapt. 10, Estimation of direct runoff from storm rainfall, USDA, Washington, D.C., 77p;

29. ***STATGRAPHICS http://www.statgraphics.com/ (accessed on 3.04.2017). 